\title{
肝薬物代謝酵素の体内時計の分子機構を基盤にした投薬タイミング
}

\author{
松永直哉
}

\section{Dosing Time Based on Molecular Mechanism of Biological Clock of Hepatic Drug Metabolic Enzyme}

\author{
Naoya MATSUNAGA \\ Pharmaceutics, Division of Clinical Pharmacy, Department of Medico-Pharmaceutical Sciences, \\ Faculty of Pharmaceutical Sciences, Kyushu University, 3-1-1 Maidashi, \\ Higashi-ku, Fukuoka 812-8582, Japan
}

(Received May 29, 2009)

\begin{abstract}
The mammalian circadian pacemaker stays in the paired suprachiasmatic nuclei (SCN). Recent several studies reveal that the circadian rhythms of physiology and behavior are controlled by clock genes. In addition, the effectiveness and toxicity of many drugs vary depending on dosing time associated with 24-h rhythms of biochemical, physiological, and behavioral processes under the control of the circadian clock. Acetaminophen (APAP) is a widely used analgesic drug, and is mainly biotransformed and eliminated as nontoxic conjugates with glucuronic acid and sulfuric acid. Only a small portion of the dose is mainly bioactivated by CYP2E1 to $N$-acetyl- $p$-benzoquinone imine (NAPQI), a reactive toxic intermediate. For APAP overdose, glucuronidation and sulfation are saturated and the formation of NAPQI increases. However, the exact mechanisms underlying the chronotoxicity of APAP have not been clarified yet. In the present study, we have clarified that there was a significant dosing time-dependent difference in hepatotoxicity induced by APAP in mice. The mechanism may be related to the rhythmicity of CYP2E1 activity and GSH conjugation. In additon, we investigated whether the liver transcription factor hepatic nuclear factor- $1 \alpha(\mathrm{HNF}-1 \alpha)$ and clock genes undergoing astriking 24-h rhythm in mouse liver contribute to the 24-h regulation of CYP2E1 activity. A significant 24-h rhythmicity was demonstrated for CYP2E1 activity, protein levels and mRNA levels. HNF-1 $\alpha$ and clock genes may contribute to produce the 24-h rhythm of CYP2E1 mRNA levels. Metabolism by CYP and GSH conjugation are common metabolic pathways for many drugs such as APAP. These findings support the concept that choosing the most appropriate time of day to administer the drugs associated with metabolic rhythmicity such as CYP and GSH conjugation may reduce hepatotoxicity in experimental and clinical situations. 24-h rhythm of CYP2E1 activity was controlled by HNF$1 \alpha$ and clock gene, in a transcriptional level. Identification of rhythmic marker for selecting dosing time will lead improved progress and diffusion of chronopharmacotherapy.
\end{abstract}

Key words__ circadian rhythm; acetaminophen; cytochrome P450 2E1; clock genes; hepatic nuclear factor

\section{1.はじめに}

多くの生体機能には日周リズム（約 24 時間を周 期とするリズム）が認められる。睡眠・覚醒，ホル モン分泌など代表的なものがあるが，血圧，体温， リンパ球の反応, 脂質代謝, 細胞分裂, 各種酵素活 性などにも日周リズムが認められる. 1,2)このような 日周リズムは，原核生物からヒトに至るまで共通し 観察され，外部からの時間情報入力のない状況下で

九州大学大学院薬学研究院薬剂学分野 (T812-8582 福 岡市東区馬出 3-1-1)

e-mail: matunaga@phar.kyushu-u.ac.jp

本総説は, 平成 20 年度日本薬学会九州支部学術奨励賞

の受賞を記念して記述したものである.
も自律的にリズムを発振する機構（体内時計）が存 在する. 3) 哺乳類動物では, 視床下部の視交叉上核 に日周リズムを発振するリズム中枢が存在し，光な どの外部刺激により 24 時間に同調し，多くの生体

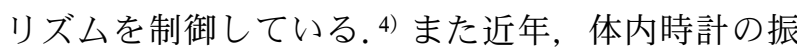
動体を構成する遺伝子 (時計遺伝子) がリズミカル に発現を繰り返すことが，体内時計の分子機構の中 枢をなすと理解されている. ${ }^{5-7)}$ またこのような日 周リズムは, 疾患や病状にも認められ，1 日の中で も発症しやすい時間帯が存在することが多く報告さ れている。 ${ }^{8,9)}$ その代表的な疾患として，気管支喘息 や消化性潰瘍, 脂質代謝異常, 高血圧などがあり, 各々の症状のリズムを考慮した薬物投与や，製剤工 
夫された薬剤が市販されるなど，時間を考慮した薬 物治療（時間薬理，時間治療）の有用性が認められ てきている. ${ }^{10,11)}$ また症状や疾患の日周リズムの有 無にかかわらず，薬物の効果や副作用発現に日周リ ズムが存在することが知られている。 その機序とし て，薬物の体内動態や，薬物の感受性に係わる生体 内の神経伝達物質, ホルモンの濃度, 受容体の数や 受容体への親和性，細胞周期などの日周リズムが影 響している. ${ }^{12-17)}$

薬物の体内動態の日周リズムは, 吸収・分布・代 謝・排泄の時間的変化により生じることが知られて いる. ${ }^{18)}$ 肝臓における薬物代謝は，一般的に肝酵素 活性及び肝血流量により制御されている。両者とも 日周リズムを示し，肝薬物代謝の日周リズムの機序 として考えられる。近年，遺伝子の網羅的解析や特 定の遺伝子を欠損した動物の解析により，肝臓の薬 物代謝に係わる遺伝子の多くに日周リズムが存在す ることが明らかとなっている. ${ }^{19,20)}$ 筆者らは肝臓の 薬物代謝の日周リズムに着目し，アセトアミノフェ ン（APAP）の肝障害が，投薬時刻により大きく異 なり，その機序として肝臓の薬物代謝酵素 CYP2E1 活性のリズムが関与していることを明らかにし

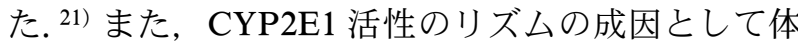
内時計の分子機構が関与していることを明らかにし た. ${ }^{22)}$ 本稿では，これら研究成果について概説する とともに, 最近の本研究に関する知見について紹介 する。

\section{2. 解熱鎮痛剤アセトアミノフェン（APAP）の} 時間薬理

解熱鎮痛薬であるAPAP が通常量投与された場 合，グルクロン酸抱合，硫酸抱合によりほとんどが 排出される. ${ }^{23)}$ 残り数\%が CYP により活性代謝物 $N$-acetyl-p-benzoquinone imine（NAPQI）となり, NAPQI はグルタチオン（GSH）により抱合をうけ 解毒される. ${ }^{23)}$ マウスにおいて APAP の代謝活性 化には CYP1A2 及び CYP2E1 が関与することが知 られている. ${ }^{24)}$ 特に CYP2E1 はその代謝に重要で あることが CYP2E1 ノックアウトマウスを用いた 研究により証明されている。一方，APAPが過量 投与された場合，グルクロン酸抱合，硫酸抱合が飽 和し，CYPによる活性代謝物 NAPQI の生成が増 加する．生成した NAPQI は GSH により解毒され るが，やがて GSH の枯渇を招きフリーの NAPQI
が肝細胞タンパクに共有結合し，酸化的ストレスを 誘発することで肝細胞障害を引き起こす. ${ }^{25-27)}$

これまでに肝臓内 GSH 量には日周リズムが存在 し, 中毒量の APAP 投与後の死亡率の日周リズム との関連性が示唆されている. ${ }^{28)} し か し ，$ 肝蔵の CYP2E1 活性の日周リズムと APAP 肝障害の投薬 時刻の影響に関してはまだ明らかとされていない。 そこでまず，自由摂食摂水，明暗周期（明期：07： 00-19：00）条件下で 2 週間飼育した 7 週齢 ICR 雄 性マウスに，6 時点 $(09: 00,13: 00,17: 00,21$ : 00, $01 ： 00,05: 00)$ のいずれかの時刻に APAP $(600 \mathrm{mg} / \mathrm{kg})$ を腹腔内投与し，投与後 7 日間の死 亡率を測定した [Fig. 1(A)]。その結果，APAP 投 与後の死亡率は，09：00 及び $05: 00$ 投与群で低值 また $21 ： 00$ 及び $01 ： 00$ 投与群で高值を示す有意な 日周リズムが存在することが明らかとなった。

APAP の急性過剩摂取による有害反応として肝障 害，腎臓障害また低血糖性昏睡などが挙げられる。 なかでも最も重大な有害反応は，肝障害であること が知られている. ${ }^{28)}$ そこで，APAP 投与後の死亡率 の日周リズムの機序を肝障害に着目し検討する目的 として，マウスに死亡例が生じない投与量（300 $\mathrm{mg} / \mathrm{kg}$ ）を 09：00 又は 21：00 に投与し，肝障害の 指標である血漿中 ALT 活性を，経時的に測定し た。その結果， $09 ： 00$ 投与群と比較し， 21：00 投 与群において，有意に ALT 活性が上昇した [Fig. $1(B)]$ 。また, APAP $(300 \mathrm{mg} / \mathrm{kg})$ を投与後, 24 時間目の肝病理組織を観察した結果，ALT 活性が 高值を示した $21 ： 00$ 投与群において，中心静脈周 辺において顕著な肝細胞の壊死が認められた [Figs. 2(A) and (B) ]. マウスに APAP (300 mg/ $\mathrm{kg}$ ) 投与後 2 時間目の肝臓を対象に，APAP 肝障 害の毒性本体である NAPQI の肝組織共有結合量を 測定した結果，壊死が顕著に認められた $21 ： 00$ 投 薬群で NAPQI の共有結合量が増加した［Figs. 2 (C) and (D)]。 以上の結果より，APAP 肝障害の 程度は投薬時刻により変化し, 死亡率の時刻の差異 と対応していた。また APAP 肝障害の投薬時刻の 影響の機序として，APAP 活性化の時刻による差 異が影響を及ぼしている可能性が示唆された。しか し，APAP急性過剩摂取による生体への影響は, 肝障害の夕ならず腎臓障害や低血糖性昏睡などを引 き起こす。このことより，APAP 投与による死亡 
(A)

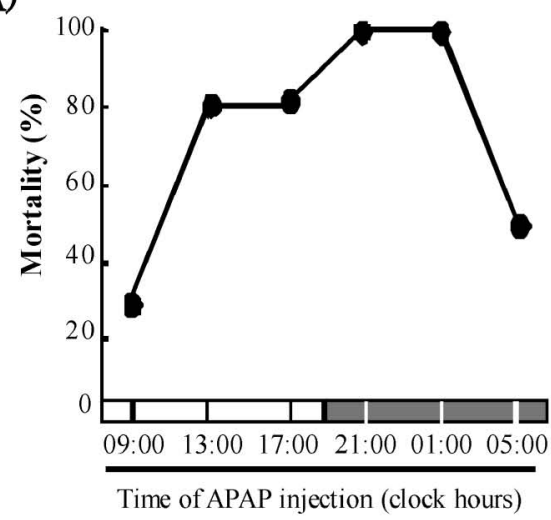

(B)

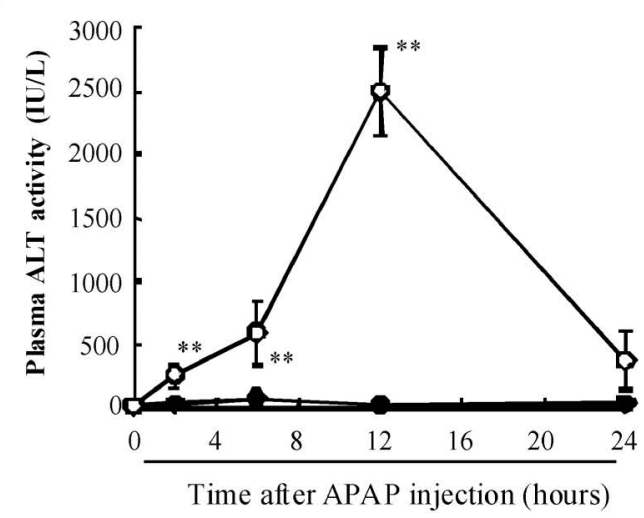

Fig. 1. Influence of Dosing Time on Mortality and Plasma ALT Activity after APAP Injection

(A) 24-h rhythm of mortality after APAP $(600 \mathrm{mg} / \mathrm{kg}$, i.p. $)$ injection. The number of deaths was recorded by 7 days after the drug injection. Values show the percentage of 10 mice. $p<0.05$; when compared among the six groups ( $\chi^{2}$-test). (B) Influence of dosing time on the plasma ALT activity after APAP (300 mg $/ \mathrm{kg}$, i.p.) injection at 09:00 (O) or 21:00 (O). Each value is the mean with S.E. of 10 mice. ${ }^{* *} p<0.01$; when compared with mice injected with APAP at 09:00 (TukeyKramer's test). Plasma ALT activity after APAP injection at 09:00 was not significantly different from that after saline injection.
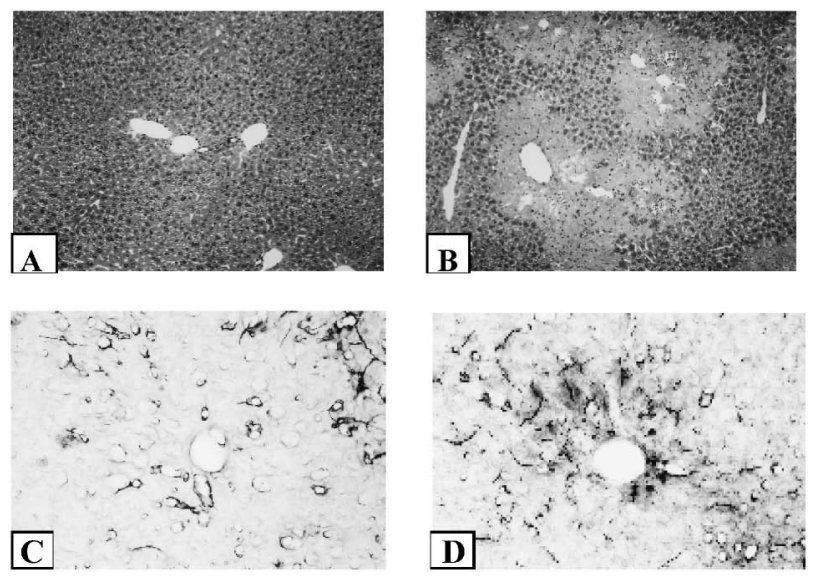

Fig. 2. Influence of Dosing Time on the Photomicrographs of Livers at $24 \mathrm{~h}$ after APAP $(300 \mathrm{mg} / \mathrm{kg}$, i.p.)

Injection at 09:00 (A) or 21:00 (B). Severe centrilobular hepatocellular necrosis was observed in the liver after the drug injection at 21:00. Hematoxylin and eosin stain. Magnification $\times 100$. Influence of dosing time on the immunohistochemical staining for NAPQI in liver at $2 \mathrm{~h}$ after APAP $(300 \mathrm{mg} /$ $\mathrm{kg}$, i.p.) injection at 09:00 (C) or 21:00 (D). Positive staining was observed in centrilobular region of liver after the drug injection at 21:00. Magnification $\times 100$.

率の日周リズムは，複数の要因が影響を及ぼしてい る可能性が考えられる.

APAP 活性化に投薬時刻の差異が存在すること が示唆されたため，APAP 活性化に重要な CYP2E1 酵素活性の日周リズムを測定した。薬物 未投与のマウスより上記 6 時点に肝臓を採取し, CYP2E1 活性を測定した結果，暗期に高值を示す 有意な日周リズムが存在することが明らかとなった [Fig. 3(A)]。また, APAP の活性化体 NAPQI の 解毒に係わる肝臟内 GSH 量を測定した結果，09：
00 に高值を示す有意な日周リズムが存在した［Fig. 3(B) ]. そこで, APAP $(300 \mathrm{mg} / \mathrm{kg})$ 投与後の肝 臓内 GSH 量の変化を経時的に測定した結果，09： 00 投与群では投与後 30 分目において肝蔵内 GSH 量は $5.46 \mu \mathrm{mol} / \mathrm{g}$ liver に低下した。一方，21：00 投与群においては投与後 30 分目に肝臓内 GSH 量 は $1.41 \mu \mathrm{mol} / \mathrm{g}$ liver に低下した [Fig. 4 (A) and (B) ]。これらの結果より，09：00 及び $21 ： 00$ 両投 与群における肝臓内 GSH 量は, APAP 投与により 低下することが示唆された。また，21：00 投与群 においては, 薬物未投与のマウス肝臓内 GSH 量の リズムのトラフ值である $6.9 \mu \mathrm{mol} / \mathrm{g}$ liver と比較し, $1 / 5$ 程度まで GSH 量は減少していた。APAP 肝障 害の機序として GSH 抱合されていないフリーの NAPQI が肝タンパクに共有結合し, 酸化的ストレ スを誘発することで起こる。実際に APAPの 21： 00 投与 2 時間後の肝臓組織には NAPQI の結合が 多く認められたことより，21：00 投与群の肝臓内 GSH 抱合能は, $09: 00$ 投与群と比較し低下してい た可能性が示唆された。以上の結果より, CYP2E1 活性が高い $21 ： 00$ 投薬群において，09：00 投与群 と比較し NAPQI 生成が増加し GSH 抱合されなか ったフリーの NAPQI による肝細胞への共有結合と 壊死が顕著に生じたと考えられる，以上の結果より，

APAP 肝障害には投薬時刻による差異が認めら れ，肝臓の CYP2E1 活性及び GSH 量のリズムを考 慮し投与することで, APAP 肝障害の程度を軽減 できることが示唆された. 
(A)

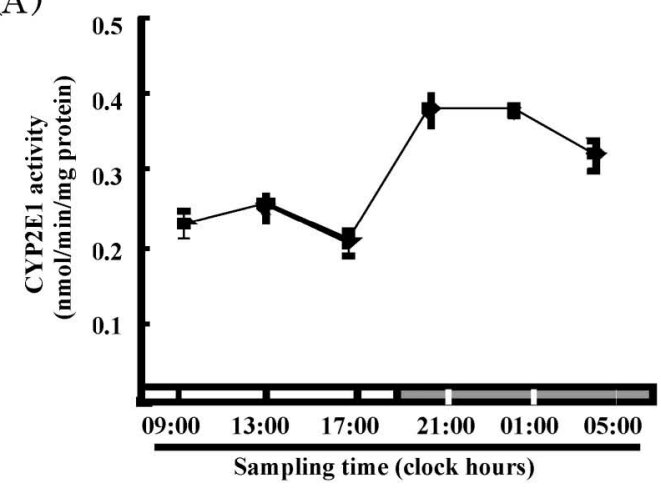

(B)

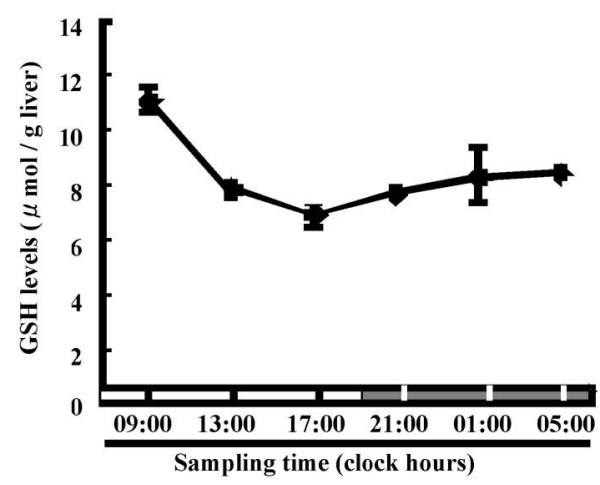

Fig. 3. 24-h Rhythm of CYP2E1 Activity and GSH Levels in Untreated Mouse Liver

(A) 24-h rhythm of CYP2E1 activity in untreated mouse liver. Each value is the mean with S.E. for 10 untreated mice. $p<0.01$; when compared among the six groups (ANOVA). (B) 24-h rhythm of GSH levels in untreated mouse liver. Each value is the mean with S.E. of 8 mice. $p<0.01$; when compared among the six groups (ANOVA).

(A)

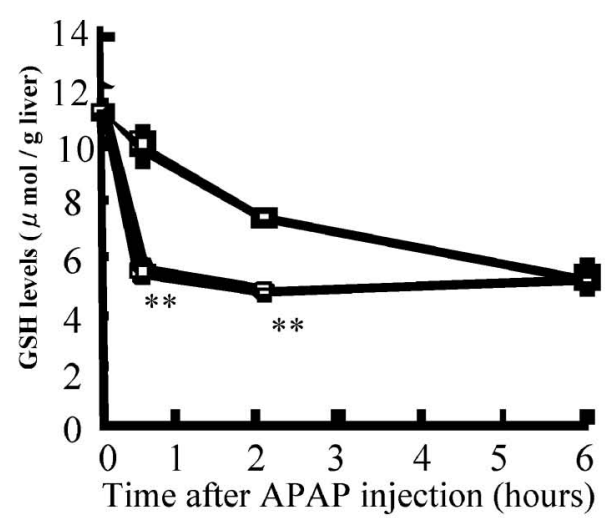

(B)

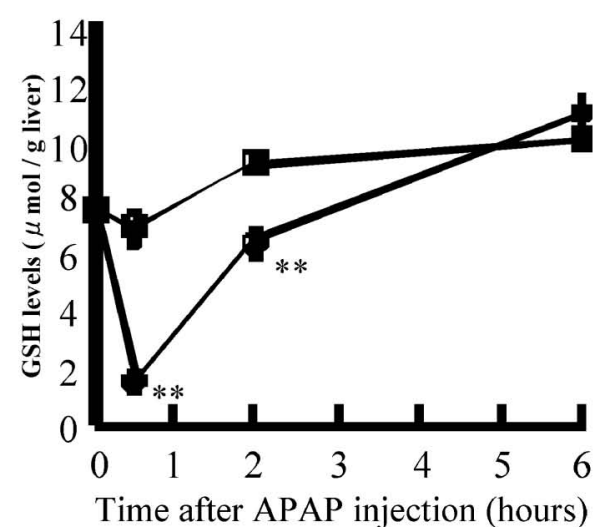

Fig. 4. Influence of Dosing Time on GSH Levels in Liver after APAP (300 mg/kg, i.p.) Injection at 09:00 (A) or 21:00 (B)

O: APAP injection at 09:00; $:$ APAP injection at 21:00; $\square$ : saline injection at 09:00; $\mathbf{\square}$ : saline injection at 21:00. Each value is the mean with S.E. of 5 mice. ${ }^{* *} p<0.01$; when compared with corresponding saline groups (Tukey-Kramer's test).

\section{3. 薬物代謝酵素 CYP2E1 活性リズムの成因解} 明

体内時計の振動体を構成する時計遺伝子が数多く 同定され，生体リズム発振メカニズムが分子レベル で明らかとなりつつある. ${ }^{6,29)}$ 哺乳類動物の体内時 計の本体は，時計遺伝子のフィーバックループ機構 により形成される。時計遺伝子である CLOCK/ BMAL1 タンパクヘテロダイマー体は, E-box と呼 ばれる DNA 上の特定の結合配列に結合し, Per 及 び Cryの各遺伝子の発現を促進する。一方，翻訳 された PER, CRY タンパクは互いに複合体を形成 し核内に移行して, 自らの転写を抑制する。近年, 網羅的な遺伝子解析や遺伝子改変動物による研究に より, 肝臓, 腎臓, 肺などの末梢臓器に発現する多
くの遺伝子に日周リズムが存在し, そのリズムは時 計遺伝子により制御されていることが明らかにされ ている.

CYP2E1 は, 主に低分子化合物や発がん物質, 医薬品ではアセトアミノフェンなどの代謝に重要な 役割を果たしている. ${ }^{30,31)}$ また，CYP2E1 には遺伝 子多型が存在し, 薬物代謝の個体差に影響を及ぼ す.32)一方, CYP2E1 活性には日周リズムが存在 し, 薬物の効果や副作用の投薬時刻の差異に影響を 及ぼしている。しかし，CYP2E1 活性の日周リズ ムの成因について，まだ明らかにされていない。 そ こでまず，マウス肝臟を上記 6 時点のいずれかに採 取し, CYP2E1 mRNA 発現リズムの測定を行った (Fig. 5). その結果, 明期後半から暗期前半に高值 
(A)

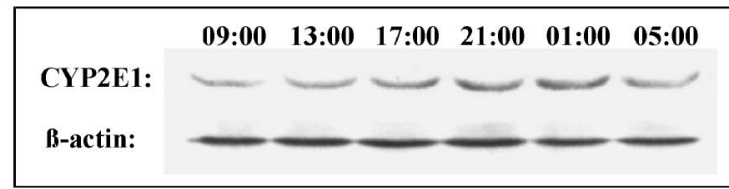

(B)

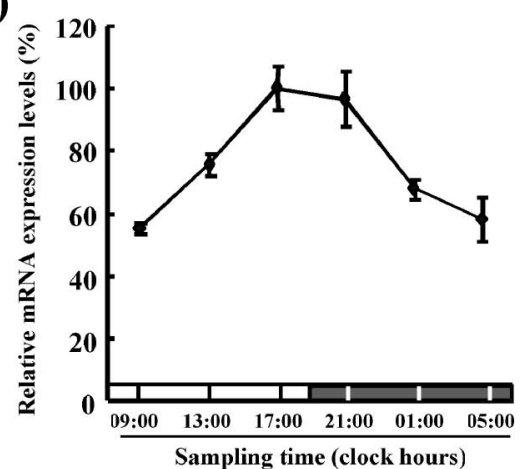

Fig. 5. 24-h Rhythm of CYP2E1 Protein and mRNA Levels in the Mouse Liver

(A) Representative Western blots for 24-h rhythm of CYP2E1 protein expression in the mouse liver. Extracts were measured by Western blot analysis with anti-CYP2E1 or anti- $\beta$-actin antibody. This examination was performed three times. (B) 24-h rhythm in relative mRNA levels of CYP2El in the mouse liver. $C Y P 2 E 1$ specific mRNA was measured by real-time PCR in untreated mouse liver cells. The data are normalized using $\beta$-actin as a control. Each value is the mean \pm S.E.M. of 6 untreated mice. Data are plotted as percentages relative to the highest value $(100 \%)$. Analysis using ANOVA revealed significant variation over time $(p<0.01)$.

を示す有意な日周リズムが存在した。また，タンパ ク量を測定した結果，暗期に高値を示し，酵素活性 のリズムと対応した。これらの結果より，活性リズ ムは転写レベルで制御されていることが示唆された. CYP を含め肝臓に発現する多くの機能性タンパク は，発達の過程で hepatic nuclear factor (HNF-1, HNF-3, HNF-4, HNF-6), D-site binding protein (DBP), CCAAT enhancer-binding protein (C/EBP) などの転写因子により，転写調節され発現する. ${ }^{33)}$ げっ歯類の肝蔵の CYP2E1 は，HNF-1 $\alpha$ により転 写促進される. ${ }^{34,35)}$ そこで生体リズムを調節してい る時計遺伝子及び HNF-1 $\alpha$ に着目し，マウスの $C Y P 2 E 1$ 遺伝子の $5^{\prime}$ 上流域を解析した。 その結果, CLOCK/BMAL1 の結合配列である E-box が 4 力 所及び HNF-1 $\alpha$ 結合配列が 1 力所存在することが 明らかとなった。この領域を対象に luciferase レ ポーターアッセイを行った結果，コントロールと比 較し HNF-1 $\alpha$ によって約 8 倍転写活性が上昇した [Fig. 6(A)]。一方，BMAL1/CLOCK による転写 は，コントロールと比較し約 2 倍促進した。また，
HNF-1 $\alpha$ の転写促進作用におよぼす時計遺伝子の抑 制因子である PER2 及び CRY1 の影響を検討した 結果，PER2 と比較し CRY1 によりその促進作用は 顕著に抑制された [Fig. 6(B)]．培養細胞に，高濃 度血清処理を施すことで, 生体で認められる時計遺 伝子の発現リズムを再現できる。리류て $C Y P 2 E 1 \mathrm{mRNA}$ 発現リズムに及ぼす HNF- $1 \alpha$ 及び CRY1 の影響を明らかにするため，HNF-1 $\alpha$ 及び CRY1 をノックダウンした培養肝細胞を作成し，高 濃度血清処理後の CYP2E1 mRNA の発現を経時的 に測定した（Fig. 7).

その結果，ノックダウンした細胞において $C Y P 2 E 1$ mRNA 発現リズムの振幅が低下した。 以 上の結果より，CYP2E1 mRNA 発現リズムは $\mathrm{HNF}-1 \alpha$ 及び CRY1 により制御されている可能性 が示唆された。真核生物の DNA は，核中でヒスト ンタンパクと複合体を形成したクロマチン構造をと っている，転写活性化メカニズムとして，転写因子 の結合が遺伝子発現に不可欠な遺伝子では，転写因 子が結合後ヒストンアセチル化活性をもつコアクチ ベーターによりヒストンがアセチル化され，クロマ チン構造が変化する。そしてポリメラーゼなどによ って構成される基本転写因子が結合し，RNAの合 成が開始される. ${ }^{36,37)}$ 時計遺伝子の 1 つである Per のプロモーターのヒストンアセチル化に日周リズム が存在し，CLOCK/BMAL1 によるPerの転写リズ ムは，コアクチベーター p300 によるヒストンアセ チル化と，CRY1/HDAC 複合体によるヒストンデ アセチル化により制御されている. ${ }^{38,39)}$ 一方, HNF-1 $\alpha$ による遺伝子の転写促進機構にはおいても p300 が HNF-1 $\alpha$ と複合体を形成し，標的となる遺 伝子のヒストンアセチル化を促進し転写を促す。 ${ }^{40)}$ そこで，HNF-1 $1 \alpha$ の転写促進作用に及ぼす CRY1 の抑制作用の機序を，ヒストンアセチル化に着目し 検討した。上記 6 時点に肝㵴を採取し, CYP2E1 プロモーター領域のヒストンアセチル化を測定した 結果，明期後半から暗期前半に高值を示し，また HNF-1 $1 \alpha$ の CYP2E1 プロモーター領域への結合量 も $C Y P 2 E 1 \mathrm{mRNA}$ 発現リズムが高值を示す時刻に 高值を示した（Fig. 8)。このことより，CYP2E1 プロモーター領域におけるヒストンアセチル化の日 周リズムが転写リズムに影響を及ぼしている可能性 が示唆された。また，HNF-1 $\alpha$ 結合領域における 
(A)

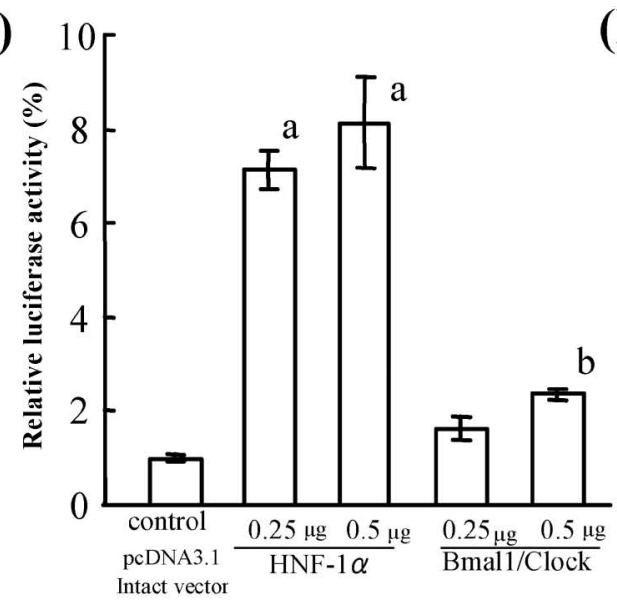

(B)

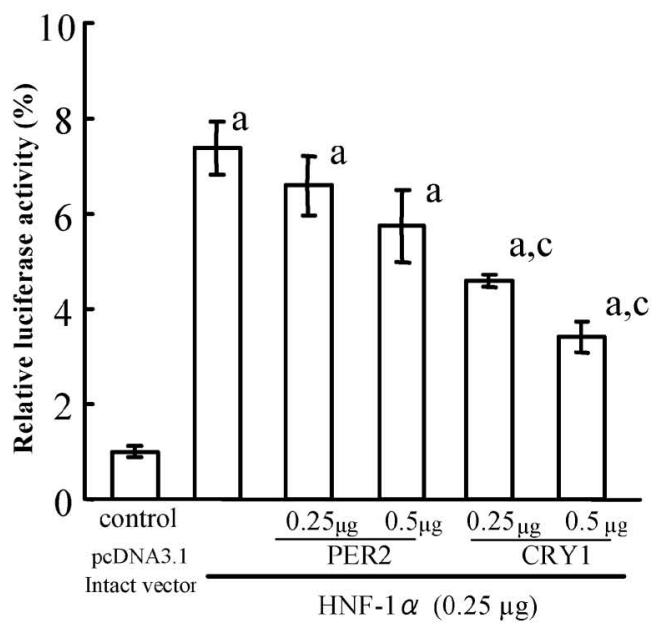

Fig. 6. Transcriptional Regulation of the Mouse CYP2E1 Gene by HNF-1 $\alpha$ and Clock Genes

(A) shows CYP2E1-luciferase reporter activity by HNF-1 $\alpha$ and clock genes in HepG2 cells. The amounts of transfected HNF-1 $\alpha$ plasmid or Clock and Bmall plasmids (each 0.25 or $0.5 \mu \mathrm{g}$ ) are listed at the bottom of each bar. All values are shown as fold increase compared to the control (pcDNA3.1 intact vector), and then the control is set at 1.0. Each value represents the mean \pm S.E.M. of five independent experiments. ${ }^{a} p<0.01$ compared with control (pcDNA3.1) using TukeyKramer's test. ${ }^{\text {b }} p<0.05$ compared with control (pcDNA3.1) using Tukey-Kramer's test. (B) shows the influence of PER2 or CRY1 on CYP2E1-luciferase reporter activity mediated by HNF-1 $\alpha$ in HepG2 cells. The amounts of transfected HNF-1 $\alpha$ plasmid $(0.25 \mu \mathrm{g})$ are listed at the bottom of each bar. The amounts of PER2 or CRY1 plasmids (each 0.25 or $0.5 \mu \mathrm{g}$ ) are listed at the bottom of each bar. All values are shown as fold increase compared to the control (pcDNA3.1 intact vector), and then the control is set at 1.0. Each value represents the mean \pm S.E.M. of five independent experiments. a $p<0.01$ compared with control (pcDNA3.1) using Tukey-Kramer's test. ${ }^{c} p<0.01$ compared with HNF-1 $\alpha(0.25 \mu \mathrm{g})$ using Tukey-Kramer's test.

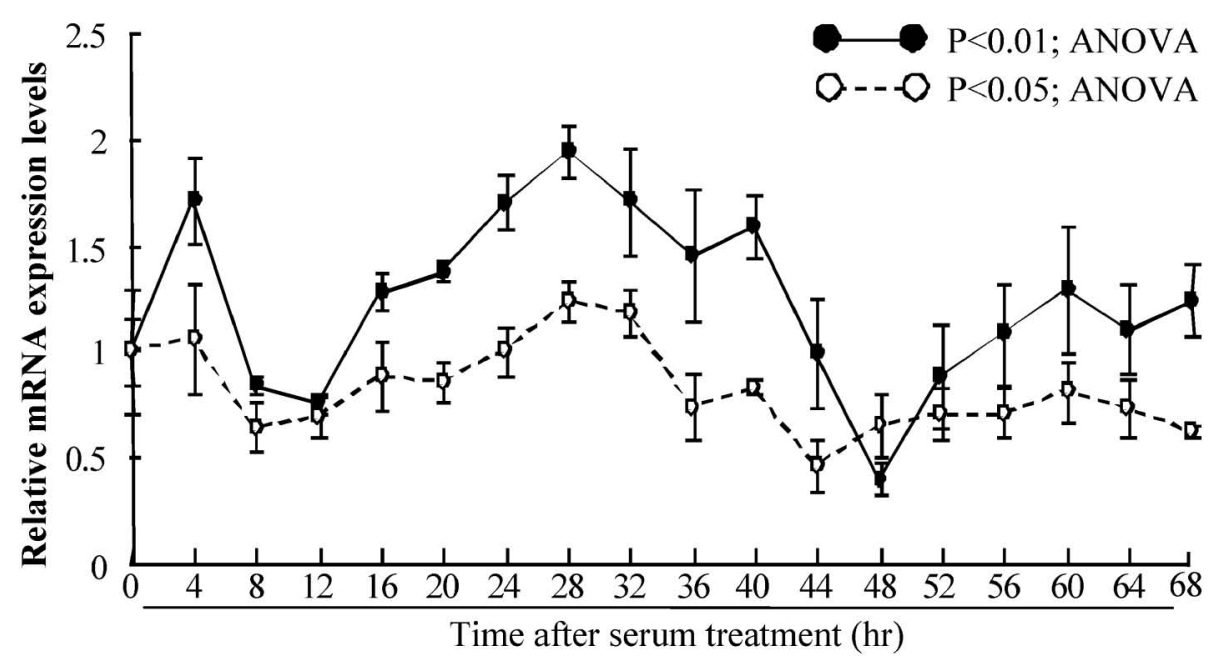

Fig. 7. Temporal Accumulation of CYP2E1 mRNA in HNF-1 $\alpha$ and Cry1 Knockdown HepG2 cells

Temporal accumulation of CYP2E1 mRNA in control cells $(-)$ or HNF-1 $\alpha$ and CRY1 knockdown cells $(O)$. The graph shows the relative band intensity of PCR products. The exponential phase of $\beta$-actin amplification in all experimental conditions occurred between the 26th and 28th cycles, and the exponential phases of $C Y P 2 E 1$ occurred between the 30th and 32nd cycles. The ratio of the amplified target to the amplified competitor (calculated by dividing the value of each CYP2El by that of internal control $\beta$-actin) was compared among groups. Each value is the mean \pm S.E.M. of three independent experiments. Data are plotted relative to the $0 \mathrm{~h}$ value after $50 \%$ serum shock. Significant time-dependent variation was found for CYP2E1 mRNA in control cells $(p<0.01$, ANOVA) or HNF-1 $\alpha$ and CRY1 knockdown cells $(p<0.05$, ANOVA).

HNF-1 $\alpha$ への p300 または CRY1 のタンパク間相互 作用を確認した結果，CYP2E1 mRNA の発現量が 低下する時刻にCRY1の結合量が高值を示し，ま た CYP2E1 mRNA 発現量が高い時刻には, p300 の結合量が高值を示した（Fig. 9)，以上の結果よ り，CYP2E1 活性リズムは，転写レベルで制御さ
れ，HNF-1 $\alpha / \mathrm{p} 300$ によるヒストンアセチル化と CRY1 によるヒストンデアセチル化の日周リズムよ り制御されていることが示唆された.

4. おわりに

生体に存在する体内時計は, 生体のホメオスタシ スの維持に重要な役割を果たしている。近年の研究 
(A)

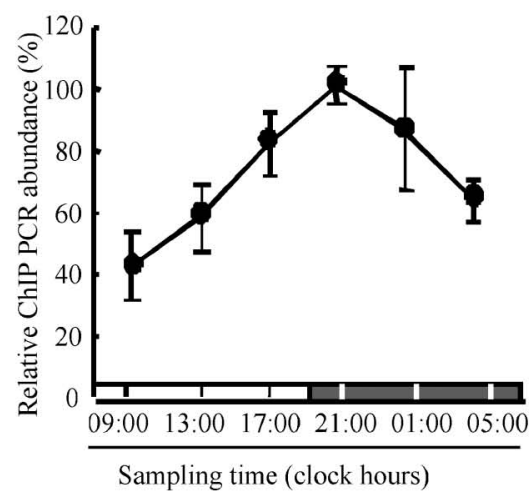

(B)

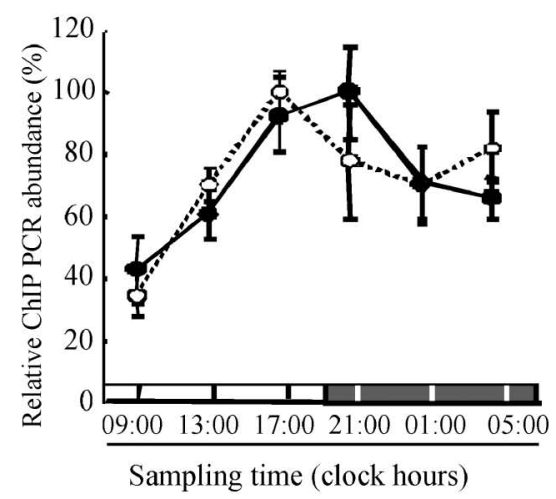

Fig. 8. Contrasting Rhythm in Transcription Factor HNF-1 $\alpha$ Binding and Chromatin Remodeling for the CYP2E1 Gene

(A) 24-h rhythm of HNF-1 $\alpha$ binding to the CYP2E1 promoter. The graph shows the relative band intensity of PCR products. PCR conditions were calibrated with known amounts of genomic DNA to confirm that amplified products were in the linear range. Data were normalized to the input control, which consisted of PCR reactions from crosslinked chromatin before immunoprecipitation. Values are the mean \pm S.E.M. for 3 untreated mice. Data are plotted as percentages relative to the highest value $(100 \%)$. A significant $24-\mathrm{h}$ rhythm was found for HNF-1 $\alpha$ binding to the CYP2E1 promoter in the mouse liver $(p<0.01$, ANOVA). (B) 24-h rhythms of $\mathrm{H} 3$ acetylation $(\mathrm{O})$ and RNA polymerase 2 binding $(\mathbf{)}$ on the $C Y P 2 E 1$ promoter. The graph shows relative band intensity of PCR products. Values are the mean \pm S.E.M. for 3 untreated mice. Data are plotted as percentages relative to the highest value (100\%). Significant 24 -h rhythms were found for $\mathrm{H} 3$ acetylation and RNA polymerase 2 binding to the CYP2E1 promoter in the mouse liver $(p<0.01$ respectively, ANOVA).

(A)

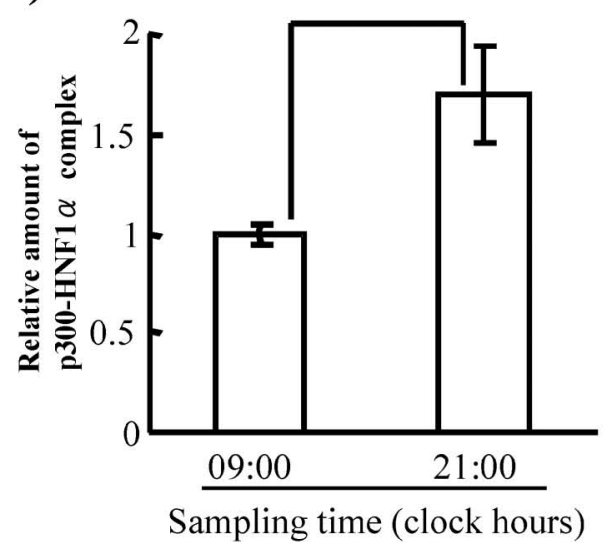

(B)

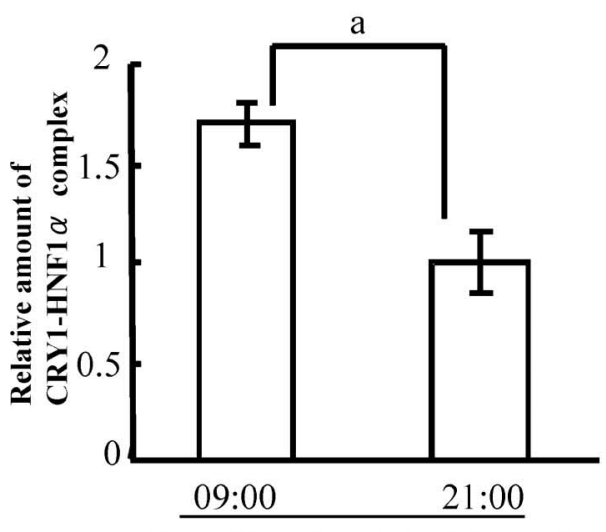

Sampling time (clock hours)

Fig. 9. Time-dependent Interactions of p300 or CRY1 with HNF-1 $\alpha$ on the HNF-1 $\alpha$ Binding Site

(A) shows the quantification of relative HNF- $1 \alpha$-p 300 association. Values are the mean \pm S.E.M. for 4 untreated mice. ${ }^{a} p<0.05$ when compared between two groups using Student's $t$-test. (B) shows the quantification of relative HNF-1 $\alpha$-CRY1 association. Values are the mean \pm S.E.M. of 4 untreated mice. a $p<0.05$ when compared between two groups using Student's $t$-test. PCR conditions were calibrated with known amounts of genomic DNA to confirm that amplified products were in the linear range. Data were normalized to the input control, which consisted of PCR reactions from crosslinked chromatin before immunoprecipitation.

により，多くの疾患の原因や病状に体内時計の関与 が認められている。.また，疾患や病状に日周リズム が認められ，個々の生体リズムに適した投薬時刻の 設定や投与方法また製剤の工夫が望まれている。こ こ 10 数年の間に, いくつかの薬物の添付文書には 投薬時刻が明示されるなど，時間治療の有用性が明 らかにされている。しかしながら，時間治療をさら に発展させる上で, 生体リズムに個体差が存在する 点が大きな障害となっている。そのため, これまで 蓄積された, 時間薬理学的所見を整理, 体系化する 必要性があると考えられる。すなわち, 個々の生体
リズムを診断する生体リズムマーカーを何にすべき か，生体リズムの中でいつ投与すべきかを決定する ことが重要となる.

本研究では肝薬物代謝酵素の活性リズムを指標に 薬物を投与する時刻を考慮することで，肝障害の程 度を軽減できることを明らかにした。また，体内時 計の分子機構を基盤に，薬物代謝酵素活性リズムの 成因を解明し，体内時計を指標とした薬物代謝酵素 活性リズムの診断が可能であることを明らかにし た．現在，個体間変動要因の代表である，薬物代謝 酵素の遺伝子多型に関する研究並びにその治療への 
応用は確立しつつある。しかし，遺伝子診断のみで 説明できない要因も存在する．近年の医薬品適正使 用の向上を目指した，テーラーメイド医療の充実を 図るためには，個体間変動の夕ならず個体内変動に 着目した研究を充実させる必要がある，今後，個体 間変動と個体内変動の情報を体系化し，真のテー ラーメイド医療の実践展開に向けた情報基盤の構築 と, 研究の発展が期待される。

\section{謝辞本研究を行うにあたり，ご指導とご支援} を賜りました諸先生方に厚く御礼申し上げます。ま た，ご協力頂きました共同研究者及び学生諸氏に感 謝申し上げます。

\section{REFERENCES}

1) Ogawa N., Ohdo S., Nihon Rinsho, 51, 27782787 (1993).

2) Ohdo S., Nakano S., Ogawa N., J. Clin. Pharmacol., 32, 822-826 (1992).

3) Dunlap J. C., Cell, 96, 271-290 (1999).

4) Reppert S. M., Weaver D. R., Nature, 418, 935-941 (2002).

5) Gekakis N., Staknis D., Nguyen H. B., Davis F. C., Wilsbacher L. D., King D. P., Takahashi J. S., Weitz C. J., Science, 280, 15641569 (1998).

6) Kume K., Zylka M. J., Sriram S., Shearman L. P., Weaver D. R., Jin X., Maywood E. S., Hastings M. H., Reppert S. M., Cell, 98, 193205 (1999)

7) Shigeyoshi Y., Taguchi K., Yamanoto S., Takekida S., Yan L., Tei H., Moriya T., Shibata S., Loros J. J., Dunlap J. C., Okamura H., Cell, 91, 1043-1053 (1997).

8) Ohdo S., Gekkan Yakuji, 44, 752-764 (2002).

9) Smolensky M. H., Labrecque G., Pharmaceutical news, 4, 10-16 (1997).

10) D’Alonzo G. E., Smolensky M. H., Feldman S., Gianotti L. A., Emerson M. B., Staudinger H., Steinijans V. W., Am. Rev. Respir. Dis, 142, 84-90 (1990).

11) Jamali F., Thomson A. B., Kirdeikis P., Tavernini M., Zuk L., Marriage B., Simpson I., Mahachai V., J. Clin. Pharmacol., 35, 1071-1075 (1995).

12) Ohdo S., Koyanagi S., Suyama H., Higuchi S., Aramaki H., Nature Medicine, 7, 356-360
(2001)

13) Koyanagi S., Kuramoto Y., Nakagawa H., Aramaki H., Ohdo S., Soeda S., Shimeno H., Cancer Res., 63, 7277-7283 (2003).

14) Nakagawa H., Koyanagi S., Takiguchi T., Kuramoto Y., Soeda S., Shimeno H., Higuchi S., Ohdo S., Cancer Res., 64, 8328-8333 (2004).

15) Viyoch J., Matsunaga N., Yoshida M., To H., Higuchi S., Ohdo S., J. Biol. Chem., 280, 6309-6315 (2005).

16) Terazono H., Hamdan A., Matsunaga N., Hayasaka N., Kaji H., Egawa T., Makino K., Shigeyoshi Y., Koyanagi S., Ohdo S., Biochem. Pharmacol, 75, 1616-1622 (2008).

17) Murakami Y., Higashi Y., Matsunaga N., Koyanagi S., Ohdo S., Gastroenterology, 135, 1636-1644 (2008).

18) Ohdo S., Drug Metab. Pharmacokinet., 22, 314 (2007).

19) Ueda H. R., Chen W., Adachi A., Wakamatsu H., Hayashi S., Takasugi T., Nagano M., Nakahama K., Suzuki Y., Sugano S., Iino M., Shigeyoshi Y., Hashimoto S. Nature, 418, 534-539 (2002).

20) Takiguchi T., Tomita M., Matsunaga N., Nakagawa H., Koyanagi S., Ohdo S., Pharmacogenet. Genomics, 17, 1047-1056 (2007).

21) Matsunaga N., Nakamura N., Yoneda N., Qin T., Terazono H., To H., Higuchi S., Ohdo S., J. Pharmacol. Exp. Ther., 311, 594-600 (2004).

22) Matsunaga N., Ikeda M., Takiguchi T., Koyanagi S., Ohdo S., Hepatology, 48, 240251 (2008).

23) Nelson S. D., Drug Metab. Rev., 27, 147-177 (1995).

24) Dahlin D. C., Miwa G. T., Lu A. Y., Nelson S. D., Proc. Natl. Acad. Sci. USA, 81, 13271331 (1984).

25) Gonzalez F. J., Toxicol. Lett., 28, 161-166 (1998).

26) Mitchell J. R., Corcoran G. B., Smith C. V., Hughes H., Lauterburg P. H., Nelson E. B., "Drug Reactions and the Liver," eds. by Davis M., Tredger J. M., Williams R., Pitman Medical, London, 1981, pp. 130-143.

27) Thomas S. H., Pharm. Ther., 60, 91-120 (1993). 
28) Schnell R. C., Bozigian H. P., Davies M. H., 4495-4505 (1990).

Merrick B. A., Johnson K. L., Toxicol. Appl. Pharmacol., 71, 353-361 (1983).

29) Gekakis N., Staknis D., Nguyen H. B., Davis F. C., Wilsbacher L. D., King D. P., Takahashi J. S., Weitz C. J., Science, 280, 15641569 (1998).

30) Tanaka E., Terada M., Misawa S., J. Clin. Pharm. Ther., 25, 165-175 (2000).

31) Gonzalez F. J., Drug. Metab. Dispos., 35, 1-8 (2007).

32) Ulusoy G., Adali O., Tumer T. B., Sahin G., Gozdasoglu S., Arinc E., Oncology, 72, 125131 (2007).

33) Cereghini S., FASEB J., 10, 267-282 (1996).

34) Ueno T., Gonzalez F. J., Mol. Cell. Biol., 10,

35) Cheung C., Akiyama T. E., Kudo G., Gonzalez F. J., Biochem. Pharmacol., 66, 2011-2020 (2003).

36) Glass C. K., Rosenfeld M. G., Genes Dev., 15, 121-141 (2000).

37) Orphanides G, Reinberg D., Cell, 108, 439451 (2002).

38) Etchegaray J. P., Lee C., Wade P. A., Reppert S. M., , Nature, 421, 177-182 (2003) .

39) Naruse $Y$. , Oh-hashi K., Iijima N., Naruse M., Yoshioka H., Tanaka M., Mol. Cell. Biol., 24, 6278-6287 (2004).

40) Soutoglou E., Papafotiou G., Katrakili N., Talianidis I., J. Biol. Chem., 275, 1251512520 (2000). 